\title{
POLITYKA HISTORYCZNA FEDERACJI ROSYJSKIEJ I ZWIAZZKU RADZIECKIEGO WOBEC POLSKI NA PRZYKŁADZIE OPISU AGRESJI ZSRR NA POLSKĘ W ŚWIETLE NARRACJI PODRĘCZNIKOWEJ
}

\author{
RUSSIANS AND SOVIETS HISTORICAL POLICY TOWARDS \\ POLAND: DESCRIPTION OF THE SOVIET INVASION \\ OF POLAND IN TEXTBOOK NARRATIVE
}

Stanisław Boridczenko*

\begin{abstract}
- ABSTRAKT
W niniejszym artykule omówiono rosyjską narrację historyczną w rodzimym szkolnictwie. Poruszony temat polega na badaniu polityki historycznej Federacji Rosyjskiej i Związku Radzieckiego. Uwagę skupiono na zawartym w podręcznikach Federacji Rosyjskiej oraz Związku Radzieckiego opisie 17 września 1939 roku. Podstawą analizy stała się szeroko zakrojona kwerenda, w trakcie której zanalizowano teksty obowiązujących od 1954 roku podręczników szkolnych. Główne uzasadnienie podjętej tematyki stanowi cieszący się popularnością w polskiej publicystyce dyskurs nawiązujący do polityki historycznej Rosji. Zgodnie z założeniem artykułu historyczna wiedza przekazywana w szkołach Rosji cechuje się starannym pomijaniem wątków związanych $\mathrm{z}$ radziecką agresją na Polskę.
\end{abstract}

Słowa kluczowe: polityka historyczna; Federacja Rosyjska; ZSRR
The article discusses the presentation of events from September 17, 1939 in the textbooks of the Russian Federation and the Soviet Union. Thematically, the topic is related to the politics of memory in Russia. The research is based on a wide-ranging analyses of the texts of the school literature published after 1958 in the USSR and in the Russian Federation. Constant discourse on the Polish political scene creates a vision of Russia neglecting Poland. As a main thesis a problem was selected concerning the indoctrination in a Russian school, which is based on ignoring the Soviet aggression on Poland.

Keywords: politics of memory; Russian Federation; USSR

* Uniwersytet Szczeciński, Wydział Humanistyczny. 


\section{WPROWADZENIE}

Po upływie 70. lat od zakończenia II wojny światowej wydaje się, że większość narodów zapomniała o jednej z kluczowych dat w chronologii tego konfliktu - dniu 17 września 1939 roku. Mamy do czynienia z jednym z najważniejszych wydarzeń z okresu światowej wojny - przystąpieniem ZSRR do konfliktu a mimo to, $\mathrm{z}$ wyjątkiem Polski, jest ono kompletnie zapomniane.

Poniższy artykuł porusza problematykę związaną ze sposobem przedstawiania zdarzeń z września 1939 roku w szkolnych podręcznikach przez jednego z uczestników tych wydarzeń - ZSRR, którego głównym spadkobiercą uznaje się Federację Rosyjską. Zagadnienie zostało wybrane $\mathrm{z}$ dwóch niezwykle istotnych powodów, które są podane w poniższym tekście.

Po pierwsze wyniki przeprowadzanych w Federacji Rosyjskiej sondaży wykazują, iż Polska przez Rosjan jest uznana za państwo wrogie. Obraz Polski jako państwa jest w opinii Rosjan zdecydowanie negatywny; Rzeczpospolita Polska nie cieszy się zaufaniem. Współczesna rzeczywistość pozostawia pytanie: jakie są przyczyny podobnego nastawienia Rosjan? Niewątpliwie do danej sytuacji doprowadziła rosyjska polityka historyczna, gdyż pamięć narodowa Rosjan nie nawiązuje do polskiej problematyki. Nie jest tajemnicą, że obecnie Federacja Rosyjska nie ma roszczeń terytorialnych do Polski; właśnie nieuregulowane spory podobnego charakteru często doprowadzają do napięć między społeczeństwami różnych krajów. Jednak konflikty o podłożu historycznym nadal wywołują obawy obydwu narodów. Dlatego też poniższa praca podejmuje tematykę związaną z polityką historyczną Federacji Rosyjskiej w kontekście opisu 17 września 1939 roku. Ze względu na to, że pamięć narodowa charakteryzuje się ciągłością, zdecydowano zbadać nie jedynie szkolne materiały do historii wydane po 1992 roku, lecz sięgnąć do podręczników od lat 50.

Po drugie agresja ZSRR na Polskę stała się leitmotivem zażartego dyskursu historyków. Temat przyciąga uwagę. Niemniej jednak do rozważenia nadal pozostaje kwestia ewolucji rosyjskiej narracji historycznej. Polscy badacze zajmujący się wschodnią problematyką nie raz wskazywali na rosyjskie próby przepisania historii. W publicystyce, a także w naukowych czasopismach wielokrotnie ukazywały się artykuły nawołujące do kolejnych szkolnych materiałów z Rosji, które ignorowały zbrodnię katyńską czy agresję ZSRR na Polskę. Wśród osób zajmujących się podobną problematyką pragnę wymienić następujących (prace których niewątpliwie uzupełniają tekst poniższego artykułu): Adama Suchońskiego (2005, 2008), Teresę Maresz (2017a, 2017b), Andrzeja de Lazari 
(2006, 2007). W Rosji polityką historyczną w stosunku do Polski w kontekście szkolnych podręczników zajmuje się Łarysa Łykoszyna (2016). Jednak o ile dana tematyka cieszy się popularnością, o tyle brakuje opracowań, które zbadałyby całość materiałów - tekstów podręczników wydanych od lat 50. do dziś dnia. Dlatego też niniejszy artykuł stanowi oryginalną próbę opracowania szkolnej literatury obowiązującej na zajęciach z historii w szkołach Federacji Rosyjskiej (do lat 90. ZSRR).

$\mathrm{Z}$ racji charakteru tekstu wybrano jakościowy rodzaj badań. Sprzyjało to wychwyceniu rosyjskich mechanizmów indoktrynacji uczniów. Metodologia polega na analizie materiałów w ich pierwotnym, nienaruszonym kształcie. Szczególna uwaga została skupiona na wykryciu intencji przekazywanej wiedzy. Wątki opisujące wrzesień 1939 roku zostały przeanalizowane pod kątem narracyjnego nastawienia do Polski.

Podstawowym celem niniejszego artykułu jest zapoznanie się z polityką historyczną Federacji Rosyjskiej za pomocą analizy tekstów podręczników w kontekście opisu napaści ZSRR na Polskę. Ponadto szczególna uwaga została zwrócona na przedstawienie okupacji wschodniej Polski w 1939 roku i rozpoczęcia II wojny światowej. Zgodnie z głównym założeniem artykułu podręczniki do historii Rosji starannie pomijają udział ZSRR w najeździe na II Rzeczpospolitą, w taki sposób kontynuując politykę historyczną przeprowadzaną przez Związek Radziecki. Dane przypuszczenie wyznacza kierunek refleksji poniższego tekstu.

\section{WRZEŚNIA 1939 ROKU W RADZIECKICH PODRĘCZNIKACH}

W ZSRR w latach 20. został stworzony jednolity system szkolnictwa, który łączył szkoły podstawowe ze średnimi. Od reformy 1924 roku dzieci rozpoczynały naukę w wieku 6 lat, a kończyły w wieku 15 albo 16 lat. W Związku Radzieckim zajęcia z historii zaczynały się od piątej klasy, natomiast tematyka II wojny światowej była poruszana jedynie na 10 roku uczestniczenia do szkoły. W wieku 15 lat uczniowie otrzymywali dyplom o niepełnym średnim wykształceniu. Dla uzyskania pełnego średniego wykształcenia trzeba było zostać na kolejny rok; jednak znaczny odsetek radzieckich dzieci wolał rozpocząć edukację w zawodowej szkole i zdobyć konkretny zawód.

Przy analizie radzieckich podręczników uwagę przyciąga styl, którym są opisywane wydarzenia historyczne. We wszystkich szkolnych książkach wymieniano te same epizody historyczne i traktowano je w ten sam sposób. Podobny fakt nie 
może być uznany za nowość, gdyż autorytarno-popagandowy charakter edukacji w ZSRR jest powszechnie znany (Maresz, 2017). Indoktrynacja uczniów polegała na opowiadaniu o przeszłości w sposób najbardziej wygodny dla rządzącej elity (Berger, 2010). Podobna rzeczywistość w znacznej mierze ułatwia analizę; wnioski wyciągnięte w stosunku do jednego podręcznika mogą być zastosowane do reszty. Ponadto istotne jest to, że paradygmat dotyczący agresji na Polskę, który był rozpracowywany przez radzieckich historyków, z upływem czasu się nie zmieniał. W trakcie analizy udało się zanotować drobne zmiany w tekstach skierowanych do uczniów, lecz sama istota przetrwała od lat 50. do upadku ZSRR.

Jakość książek, które zostały zbadane, znajduje się na bardzo niskim poziomie. Papier wydruku jest złej jakości. Dotyczy to podręczników z całego okresu radzieckiego. Podstawą analizy stały się następujące materiały: Nowiejszaja istorija dla 10 kłassa (1939-1982) (Furajew, 1983), Nowiejszaja istorija (1939-1974) (Furajew, 1975), Istorija SSSR dla 9-10 kłassow sriedniej szkoły (Jepifanow, Fiedosow, 1965), Istorija SSSR. Epocha socyalizma. Uczebnoje posobije dla 9-10 kłassow sriedniej szkoły (Kim, 1969), Istorija SSSR (1938-1978 gg.) (Kim, 1980), Istorija SSSR. Czast' 3 (Pienkratowa, 1952). Zawarta w nich ikonografia z upływem czasu nie ewoluowała. Fotografie, a także rysunki (karykatury) w paragrafach opisujących 17 września 1939 roku w większości przypadków nie były wykorzystywane. Natomiast przy opisie niemieckiej agresji na Polskę czy polityki ZSRR na Kresach używano zdjęć. Przykładowo paragraf opisujący rozpoczęcie II wojny światowej w podręcznikach Furajewa jest zilustrowany zdjęciem zmechanizowanej kolumny niemieckich żołnierzy na tle ruin polskiego miasta (co wynika z opisu do zdjęcia) w tle. W podręcznikach Maksyma Kima w badanym podrozdziale (opisującym zewnętrzną politykę ZSRR w latach 1939-41) umieszczono zdjęcie mieszkańców Mołdawii z radością witających radzieckich żołnierzy. Warto zaznaczyć, że w radzieckich materiałach ilustracje były wykorzystywane bardzo rzadko. Podane twierdzenie dotyczy w równej mierze map i wykresów. Także w zbadanych tekstach nie udało się odnaleźć wypisów źródłowych.

Podobna sztywność radzieckiego systemu przekazu wiedzy historycznej może być uwarunkowana wieloma czynnikami (np. Bagdarasiam i in., 2009). Najistotniejszymi są: jednolitość podręczników (treść książek powtarzała się w każdym wydaniu niezależnie od autorstwa), wykorzystanie tego samego historycznego paradygmatu (stworzonego przez Marksa i Engelsa, później dopracowanego przez Lenina), centralizacja systemu edukacji (plany szkolnych zajęć, podobnie jak szkolna literatura, były zatwierdzane na poziomie Narodowego Ministerstwa Edukacji) oraz ograniczona ilość wydawnictw, które miały prawo do publikacji 
podręczników. Jednolitość zauważalna jest na każdym poziomie badania, gdyż odnosi się nawet do słownictwa. Radziecka szkolna literatura wyróżnia się materialistycznym nastawieniem do historii i brakiem sprzeczności, które mogą być uznane za typowy problem rosyjskich podręczników z lat 90. (Maresz, 2017). Analiza ujawniła, że podręczniki wykorzystywane w radzieckich szkołach liczyły dziesiątki wydań i były napisane przez ograniczone grono zaufanych historyków (większość poddanych analizie podręczników była napisana przez Maksima Kima tudzież Wiktora Furajewa).

Ze względu na to, że wrzesień 1939 w szerszym kontekście historycznym należy do tematu II wojny światowej, w ramach niniejszej pracy niezbędne stanie się uwzględnienie radzieckiej chronologii zdarzeń, gdyż pomoże to zrozumieć nastawienie osób piszących szkolne materiały do podniesionej w artykule problematyki. Jakościowe badanie nad danymi tekstami będzie sprzyjało wychwyceniu autorskiej narracji o Polakach i Polsce.

Tekst opisujący rozpoczęcie II wojny światowej w radzieckiej szkolnej literaturze $\mathrm{z}$ reguły mieścił się $\mathrm{w}$ podrozdziale zatytułowanym „wyzwolenie Zachodniej Ukrainy i Zachodniej Białorusi”. Tradycja podobnego tytułowania sięga lat 50. Wykazała to obszerna analiza szkolnych materiałów ZSRR, gdyż nazwa pozostawała bez zmian do lat 90. Jak wynika z tytułu, opisanie wrześniowych wydarzeń powinno być uznane za manipulacyjne. Trzeba zaznaczyć, że sowiecka historiografia miała nieprzychylne nastawienie do Polski w każdym jej kształcie (za wyjątkiem Polskiej Rzeczypospolitej Ludowej). Po opisie wyzwolenia Kresów spod „polskiego jarzma” autorzy radzieccy przechodzili do zagadnień związanych z polityką wewnętrzną ZSRR. W tym dla wątku poświęconego Polsce oraz narodowi polskiemu nie było miejsca, gdyż historycy omawiali realizację przedwojennego planu pięcioletniego.

Agresja ZSRR na Polskę była uzasadniana między innymi tym, że Białorusini i Ukraińcy w II Rzeczypospolitej Polskiej stanowili pozbawioną praw mniejszość. „Białorusini i Ukraińcy zamieszkiwali w Polsce w statusie osób pozbawionych praw. Ich język, kultura i narodowe tradycje zostały wyeliminowane. Ukraińsko-białoruskie szkoły [w okresie międzywojennym] były zlikwidowane. Większość ludności Zachodniej Ukrainy i Zachodniej Białorusi stanowili analfabeci. Ukraińcy i Białorusini byli pozbawieni prawa zajmowania stanowisk w aparacie państwowym. Na wschodnich terenach, które polski rząd nazywał „Kresami”, większość uprawianych ziem dzierżawiły osoby pochodzenia polskiego. (...) Wraz ze szlachtą krwiopijcą Białorusinów i Ukraińców byli kułacy, czyli tzw. osadnicy”. (Pienkratowa, 1952). Podobna narracja może być 
odczytana we wszystkich radzieckich podręcznikach opisujących II Rzeczpospolitą.

W kolejnych paragrafach materiałów szkolnych z reguły opisywano to, co dziś jest znane pod nazwą wielkiej wojny ojczyźnianej. Dzieliła się ona na trzy etapy. Pierwszy sięgał bitwy o Moskwę. Drugi dotyczył tzw. „radykalnej zmiany” (bitwa Stalingradzka, bitwa na Łuku Kurskim i przeprawa przez Dniepr). Trzeci i ostatni obejmował wyzwolenie zachodnich republik Związku Radzieckiego i krajów Europy spod niemieckiej okupacji. Jedynym miejscem w ramach narracji o wielkiej wojnie ojczyźnianej, w którym odwoływano się do Polski, był trzeci etap. Zaczynając od lat 50., w paragrafie o ofensywie Armii Radzieckiej w latach 1944-1945 umieszczano wzmiankę wskazującą na bratnie relacje między Polską a ZSRR. „Po wyzwoleniu Białorusi i znacznej części Litwy, Armia Radziecka wkroczyła na ziemi sojuszniczej Polski i wkrótce dotarła do niemieckich granic”. (Pienkratowa, 1952). Autorzy zwracali uwagę na Armię Polską. „Ramię w ramię z Armią Radziecką o wyzwolenie Polski od faszystowskich okupantów walczyła Armia Polska. Została ona utworzona przy bratnim wsparciu Związku Radzieckiego". (Kim, 1969). Podobny przekaz narracyjny pozostał bez zmian w podręcznikach późniejszych lat - 70. i 80. Co więcej, poszerzał się o nowe wątki, ukazujące trwałą przyjaźń między ZSRR a PRL.

Analiza jakościowa radzieckich tekstów wykazała, iż podręczniki jednocześnie reprezentowały dwa nastawienia do Polski i narodu polskiego. Pierwsze dotyczyło II Rzeczpospolitej. Wyróżniało się jawną nieprzyjaźnią i wrogością. Przykładowo, uczniom wyjaśniano, że agresja 17 września została dokonana na „naturalnym rywalu” (Furajew, 1983). Natomiast przy opisie zdarzeń po ataku Niemiec na ZSRR, Polskę zaliczano do kręgu najbliższych sojuszników, a w stosunku do narodu polskiego używano określenia „bratniego” (Kim, 1969). Dana narracyjna „luźnośç” jest łatwa do wyjaśnienia. Determinującym bowiem był czynnik ideologiczny.

Analiza potwierdziła popularną tezę o tym, iż w zimnowojennym okresie radziecki system edukacji ignorował międzynarodowy aspekt II wojny światowej (która w radzieckiej historiografii została zastąpiona przez koncepcje wielkiej wojny ojczyźnianej) oraz istotność roli Związku Radzieckiego we wzniecaniu konfliktu. Tematyka światowej wojny w tekstach została wyczerpana drobnymi wzmiankami o konferencjach szefów państw koalicji antyhitlerowskiej oraz wskazaniem na antynarodowy charakter konfliktu.

W tekście opisującym wrzesień 1939 roku autorzy reprezentują pogląd, zgodnie z którym główną przyczyną wojny stał się antagonizm imperialistycznych 
mocarstw rywalizujących o dominację nad światem. $Z$ powodu podobnego założenia zbrojne starcie między Polską a Niemcami było uznane za niegodne uwagi, gdyż ze strony Polski konflikt nie miał charakteru narodowego (jedynie typowo burżuazyjnego). „Rozpoczęła się II wojna światowa, która na pierwszym etapie miała charakter imperialistyczny. Stanowiła kontynuację polityki dwóch imperialistycznych ugrupowań, które konfliktowały o rynki zbytu, źródła surowców, strefy wpływów kapitału” (Kim, 1975). Związek między ZSRR a sojusznikami charakteryzował się jako „skomplikowany i sprzeczny” (Jepifanow, Fiedosow, 1965). II Rzeczpospolita (a także rząd na uchodźstwie), Wielka Brytania i Stany Zjednoczone zostały uznane za państwa kapitalistyczne - geopolitycznych przeciwników ZSRR. Autorzy radzieckich podręczników wskazują, że przywódcy sojuszniczych krajów działali wyłącznie we własnych interesach (Furajew, 1983). Rzeczypospolitej Polskiej wytykano niechęć do współpracy ze Związkiem Radzieckim w okresie międzywojennym i jej brutalną politykę wobec Białorusinów oraz Ukraińców (Kim, 1980).

Pakt Ribbentrop-Mołotow stanowi temat bezpośrednio związany z poruszonym w poniższym artykule, gdyż każda analiza września 1939 roku potrzebuje szerszego traktowania zdarzeń, które doprowadziły do rozpoczęcia II wojny światowej. W trakcie zapoznania się z tekstami radzieckich podręczników zostały odnotowane zmiany, które miały w nich miejsce. Temat porozumień z Niemcami w literaturze skierowanej do uczniów nie został pominięty. Narracja podręcznikowa lat 50. skupiała się na Stalinie i jego polityce, która dała ZSRR czas na przygotowanie się do wojny. Po śmierci Stalina i zmianach w elicie rządzącej materiały szkolne niejako zmieniły nastawienie i całość zasług w sprytnej polityce została przypisana partii. Trzeba zaznaczyć, iż w radzieckiej literaturze termin „pakt Ribbentrop-Mołotow” nie istniał, gdyż używano łagodniejszego określenia „umów z Niemcami”. Dane „umowy” były traktowane wyłącznie z pozycji państwa, które zwyciężyło w II wojnie światowej; innymi słowy narracja podręcznikowa przekonywała uczniów, iż pakt z Hitlerem wzmocnił pozycję ZSRR, co później zostało wykorzystane w trakcie wojny z III Rzeszą. Na podstawie powyżej zaznaczonego przekazu narracyjnego, udowadniano tezy o rozsądnej polityce prowadzonej przez komunistyczną partię. W podręcznikach zaznaczano, że partia zawsze dąży do pokoju, jednak jest zdolna do obrony interesów narodu i robotniczej klasy. Przy omówieniu „umów z Niemcami” fakt istnienia II Rzeczypospolitej Polskiej był zapominany, gdyż Polska według autorskich intencji była terenem bez własnej tożsamości. 
W ZSRR pakt, który umożliwił rozpoczęcie światowej wojny, był traktowany w kontekście konfliktu między „siłami reakcji” a „siłami postępu społecznego” (Kim, 1969). II Rzeczpospolita Polska znajdowała się po stronie „sił reakcji”, które powinny były ustąpić miejsca rodzącym się „siłom postępu”. Podobna pozycja autorów doprowadzała do ignorowania Polski oraz narodu polskiego. Świadczy o tym abstrakcyjny opis dziejów polskich. Z analizy źródeł wynika, iż II Rzeczpospolita stanowiła przykład państwa skazanego na upadek, państwa antynarodowego. Autorzy podręczników z lat 80. twierdzili, że zawarcie paktu z Niemcami pozwoliło uniknąć wojny na dwa fronty, co skutkowało przeniesieniem konfliktu na późniejszy okres, kiedy zdolność ZSRR do obrony się zwiększyła. Ponadto autorzy próbowali przekonać uczniów, iż pakt Ribbentrop-Mołotow uniemożliwił utworzenie jednego antysowieckiego bloku imperialistycznych mocarstw, który miałby na celu zbrojną interwencję przeciwko Związkowi Radzieckiemu (Furajew, 1983). Trzeba zaznaczyć, iż uczniowie o fakcie zawarcia tajnych protokołów do tego paktu nie byli informowani. Dopiero po upadku ZSRR na stronach podręczników zaczęły się pojawiać wątki opisujące planowany podział Europy między Stalinem i Hitlerem na strefy okupacji.

Rozdziały opisujące wrzesień 1939 roku zawierają dwa ważne zagadnienia. Pierwsze reprezentuje stanowisko radzieckich ideologów w sprawie 17 września i okupacji Kresów przez ZSRR (a w szerszym kontekście całości zdarzeń od 1 września). Natomiast drugie ma bardziej ogólny charakter i nawiązuje do wątku podnoszącego problematykę międzynarodowych relacji w okresie międzywojennym.

Rozpoczęcie II wojny światowej jest opisywane w następujący sposób: „1 września 1939 r. wojska faszystów [niemieckie] zaatakowały Polskę. 3 września Anglia i Francja, które obiecały Polsce pomoc, wypowiedziały wojnę Niemcom. Na to Hitler powiedział: „to nie znaczy, że będą walczyć”. I rzeczywiście, Anglia i Francja zdradziły Polskę w ten sam sposób, jak zdradziły Czechosłowację (...) Rządzące zachodnimi państwami spodziewały się, że po zwycięstwie w wojnie z Polską, Niemcy zaatakują ZSRR” (Furajew, 1983). Ten fragment tekstu pokazuje główną tezę rozpracowywaną przez radzieckich historyków: cała odpowiedzialność za II wojnę światową spoczywa na państwach zachodnich, gdyż to one chciały wykorzystać Hitlera przeciwko ZSRR. Zgodnie z tą samą tezą Polska stała się ofiarą rozgrywek politycznych swoich sojuszników, którzy nigdy nie zamierzały jej bronić, lecz przeciwnie - jej istnienie przeszkadzało planom wzniecania konfliktu między III Rzeszą a Związkiem Radzieckim. 
Opisując wrześniowe walki Polaków z Niemcami, radzieccy historycy stosują komunistyczny paradygmat, który bagatelizuje czynny udział narodu i elit rządzących w obronie państwa polskiego. Wymieniona koncepcja jest bardzo często spotykana na stronach radzieckich podręczników. Polega ona na założeniu, że jedynie w państwach „progresywnych” (komunistycznych) istniały warunki umożliwiające odpór agresorowi. W burżuazyjnych państwach bowiem elita rządząca bardziej bała się własnego narodu niż nazistów (Jepifanow, 1965). Jedyny wyjątek od danej reguły ignorowania czynnego udziału Polaków w oporze stawianym Niemcom stanowi opisanie dziejów proletariatu i aktywistów komunistycznych. Niemniej jednak narracja tekstu nie pozostawia wątpliwości, iż system społeczny II Rzeczypospolitej był o tyle zacofany, że podobni patrioci stanowili mniejszość. „Po zajęciu znacznej części polskich terenów przez hitlerowców rząd polski razem z dowództwem wojskowym uciekł za granicę, pozostawiając naród. Wiele jednostek wojskowych, a także mieszkańców Warszawy i innych polskich miast, bohatersko walczyło z wrogiem. Na czele obrońców polskich ziem stali robotnicy. Polscy komuniści, opuszczając więzienia, brali do rąk broń i stawiali opór okupantom. Jednak przewaga była po stronie hitlerowców" (Furajew, 1983).

Według autorów Robotniczo-Chłopska Armia Czerwona wkroczyła na polskie terytorium (trzeba zaznaczyć, iż w tekstach zbadanych w danym opisie zawsze wykorzystywano określenie „Zachodnia Białoruś i zachodnia Ukraina” zamiast wschodnia Polska bądź Kresy), jednak to była wojna wyzwoleńcza w intencji ochrony ludności białoruskiej i ukraińskiej. W uzasadnieniach historycy radzieccy często sięgali po tzw. internacjonalny obowiązek Związku Radzieckiego w stosunku do Białorusinów oraz Ukraińców (ciekawy jest brak wspomnień o Litwinach, gdyż między innymi okupowano teren później przekazany Republice Litewskiej). „Osiągnięcia hitlerowców na wschodzie stanowiły zagrożenie nie tylko dla ZSRR, lecz dla ludności zachodniej Ukrainy i Białorusi. Tereny te stały się częścią Polski w wyniku podpisania traktatu ryskiego w 1921 roku. Internacjonalny obowiązek przymuszał Związek Radziecki do obrony życia i majątku Ukraińców i Białorusinów [przed hitlerowcami]. Ludność z radością witała wkraczające oddziały Armii Czerwonej i wyrażała jednoznaczną chęć do zjednoczenia się z Ukraińską i Białoruską Republikami Radzieckimi” (Furajew, 1983).

Powyżej cytowane fragmenty podręczników ujawniają spojrzenie radzieckiego społeczeństwa na tę problematykę. Ten pogląd na historię opiera się na założeniu, iż radzieccy żołnierze nie okupowali polskich ziem. Jedynie wkraczali na tereny pozbawione organów władzy. Odbywało się to przy aktywnym 
wsparciu ludności lokalnej. Szkolna narracja historyczna starannie podkreślała następujące fakty: brak oporu (ze strony ludności i polskich jednostek wojskowych) oraz przejawy masowego wsparcia przez populację zachodniej Białorusi i Ukrainy wkraczających oddziałów Armii Czerwonej.

Nie zagłębiając się w spory o charakterze historycznym, trzeba zaznaczyć, że autorzy szkolnej literatury starali się stworzyć obraz najbardziej korzystny dla Związku Radzieckiego. Świadczy o tym opisanie problematyki narodowej na Wschodnich Kresach. W radzieckich podręcznikach postrzegano ją wyłącznie przez pryzmat Białorusinów i Ukraińców, pomijając polską wizję. „W wyniku [rozdziału II Rzeczypospolitej] około 13 mln Ukraińców i Białorusinów stało się częścią ZSRR. Marzenie robotników z Zachodniej Ukrainy i Zachodniej Białorusi o zjednoczeniu z ZSRR zostało spełnione" (Pienkratowa, 1952). W trakcie kwerendy na stronach szkolnych materiałów nie udało się znaleźć żadnych wzmianek o Polakach z terenów dołączonych do ZSRR. Granice z 1939 roku w radzieckich szkolnych materiałach określano mianem „naturalnych”. Zaznaczano, że nowe granice państwowe przebiegały wzdłuż granic etnicznych.

\section{PROBLEMATYKA 17 WRZEŚNIA 1939 ROKU W ROSYJSKICH PODRĘCZNIKACH}

Obecnie w Rosji ukształtował się jednolity system szkolnej edukacji. Kształcenie dziecka trwa jedenaście lat (wcześniej istniała możliwość uzyskania dyplomu o niepełnym średnim wykształceniu na dziewiątym roku). Rosyjskie dzieci zaczynają uczęszczać do szkół w 7 lub 8 roku życia. Wykształcenie średnie zdobywa się po ukończeniu XI klasy. Temat II wojny światowej jest poruszany $\mathrm{w}$ trakcie zajęć w IX oraz XI klasach (natomiast wstępne zapoznanie się z historią odbywa się w 5 roku uczęszczania do szkoły).

Podręczniki rosyjskie odróżniają się od radzieckich tym, że są bogato ilustrowane, na ich stronach znajdują się liczne mapy, obrazki i wykresy. Jakość druku jest lepsza. Jednak warto zaznaczyć, że ikonografia w nich zawarta odróżnia się od radzieckiej różnorodnością i niejednolitością. Poniższy tekst został napisany w oparciu o wyniki analizy następujących książek: Istorija Rossii. XX-naczało XXI w. 9 kłas (Daniłow, Kosulina, Brandt, 2012), Istorija Rossii. XX-naczało XXI w. 9 kłas (Daniłow, Kosulina, Brandt, 2013), Rossijskaja cywilizacyja. IX-naczało XX w. (Ionow, 2001), Istorija Rossii. 9 kłass (Izmozik i in., 2015), Istorija. Istorija Rossii. 9 klas (Kisielew, Popow, 2016), Nowiejszaja istorija zarubieżnych stran 
1914-1997. 9 klass (Kreder, 2005), Istorija. Wsieobszczaja istorija. 11 kłass (Plenkow i in., 2013), Istorija Rossii, XX-naczało XXI wieka. 11 kłass (Szestakow, 2012), Istorija. Rossija i mir. 11 kłass. (Wołobujew i in. 2013), Istorija Rossii. XX-naczało XXI w. 9 kłas. (Wołobujew, Żurawlew, Nienarokow, Stepaniszczew, 2010). Temat okupacji Kresów w podanych podręcznikach z reguły zajmuje oddzielny paragraf bądź akapit w podrozdziale opisującym rozpoczęcie II światowej wojny. Podobnie jak w radzieckich szkolnych materiałach, tekst o wrześniu 1939 roku nie uzupełniono ani zdjęciami, ani rysunkami. Aczkolwiek podrozdziały opisujące rozpoczęcie II wojny światowej mają liczne obrazki. Przykładowo: reprodukcja angielskiej karykatury z maszerującym Hitlerem i Stalinem (Wołobujew i in. 2013), zdjęcie podziału majątków ziemskich w Estonii w 1940 roku (dane zdjęcie już było wykorzystane w podręcznikach Maksyma Kima) (Daniłow, Kosulina, Brandt, 2013, 2012), zdjęcie Stalina z Ribbentropem po podpisaniu traktatu między ZSRR i Niemcami w 1939 roku (Wołobujew, Żurawlew, Nienarokow, Stepaniszczew, 2010).

Każdy podrozdział rosyjskiego podręcznika kończy się pytaniami skierowanymi do uczniów. Dane zagadnienia bardzo rzadko odwołują się bezpośrednio do tematyki radzieckiej agresji na Polskę. Jednak wśród nich spotyka się i takie, które zachęcają do zastanowienia się nad stalinowską polityką z lat 30. Część związana jest $\mathrm{z}$ „paktem o nieagresji” między Związkiem Sowieckim a hitlerowskimi Niemcami. W danej rubryce obraz Polski znajduje się na drugim planie.

Od końca lat 80. w historiografii (wtedy jeszcze Związku Radzieckiego) rozpoczął się nowy etap, związany z udostępnieniem społeczności nowych materiałów z zakresu historii ZSRR. Doprowadziło to do masowej publikacji prac na temat II wojny światowej, które ujawniały dotąd nieznaną wizję 1939 roku. Niemniej jednak w podręcznikach szkolnych jeszcze długo kontynuowano radziecką tradycję przekazu wydarzeń z minionych lat. Co więcej, nadal jedynie federalny rząd miał monopol w sferze edukacji. Szkolne jednostki nie posiadały żadnej autonomii. Dopiero od połowy lat 90 . rosyjskie szkoły uzyskały prawo do samodzielnego wyboru podręczników do historii Rosji, a także do układania własnego programu nauczania. Właśnie wtedy w Federacji Rosyjskiej zaczęły ukazywać się eksperymentalne szkolne materiały, których autorzy próbowali napisać „nową” historię dla dzieci w wieku szkolnym.

$\mathrm{Z}$ powodu rezygnacji systemu oświaty z obowiązujących państwowych standardów grono autorów zaangażowanych w napisanie podręczników szkolnych poszerzyło się. Wielu z nich było wspieranych przez zagraniczne fundusze udzielające dotacji na napisanie książek z historii Rosji. Najbardziej znanym 
w danej dziedzinie był fundusz Sorosa (który został założony przez George;'a Sorosa - amerykańskiego inwestora, milionera, a także filantropa), który po upadku Związku Radzickiego finansował pisanie i zakup literatury dla szkół. Przy jego aktywnym wsparciu zostały opublikowane podręczniki I.N. Ionowa (2001), A.P. Bogdanowa, E.E. Wiazemskiego, O.J. Strełowa, M.W. Korotkowa, A.A. Kredera (2005), O.S. Soroko-Cupy, A.A. Lewandowskiego (2013) i wielu innych autorów. Doprowadziło to do udostępnienia młodemu pokoleniu ukrywanych informacji. Między innymi po raz pierwszy w ramach szkolnego programu zostały omówione wątki dotyczące paktu Ribbentrop-Mołotow (w kontekście tajnych protokołów do tegoż paktu) oraz wrześniowej agresji ZSRR. Na stronach podręczników napisanych przez wyżej wymienionych historyków potępiano politykę Związku Radzieckiego i uznano, że 17 września 1939 roku miała miejsce agresja przeciwko państwu niepodległemu. Po raz pierwszy odrzucono wcześniej dominującą koncepcję zjednoczenia bratnich republik (Białorusi i Ukrainy) i wskazano, że był to akt okupacji ziem polskich. Treść szkolnej literatury tych lat po raz pierwszy poruszyła polską problematykę z nieco innej perspektywy. Nie pomijała faktu, iż znaczny odsetek populacji terenów dołączonych do ZSRR miał polskie pochodzenie i z powodu swej narodowości był prześladowany przez funkcjonariuszy służb bezpieczeństwa Związku Radzieckiego. Co więcej, Igor Dolucki w swym podręczniku zrezygnował z wielkiej wojny ojczyźnianej i zastąpił ją II wojną światową. Podobna zmiana terminologii doprowadziła do uwzględnienia uczniom szerszego grona zagadnień, w tym związanych z agresją ZSRR na Polskę. Powyżej wymienione fakty wskazują na to, iż właśnie podręczniki z lat 1995-2004 mogą być uznane za najbardziej przychylne Rzeczypospolitej Polskiej. Co więcej, właśnie na tym etapie powstały prace, które traktowały proces historyczny z perspektywy przyjęcia założeń, które dominują w polskiej historiografii. Podobna przychylność i otwartość niewątpliwie mogła spowodować znaczne zmiany w świadomości młodego pokolenia Rosjan, czy przynajmniej pozostawić piętno na ich umysłowości. Jednak podobne badania znajdują się poza tematyką niniejszego artykułu, gdyż jest on skupiony na analizie tekstów podręczników i narracji historycznej.

Działalność zagranicznych fundacji wspierających liberalne badania była nietrwała. Od samego początku rosyjscy eksperci byli krytyczne nastawieni w stosunku do obcych fundacji, uznając, że orientacja ideologiczna książek opublikowanych przy ich wsparciu jest antyrosyjska. W latach 2000 federalny rząd Rosji stopniowo zwalczał przejawy wolności lat 90., w tym w systemie oświaty. Treść podręczników zmieniła się. Obecnie zauważalna jest tendencja 
do przywrócenia paradygmatów rozpracowywanych w komunistycznym okresie. Wtedy uzyskiwana w szkołach wiedza historyczna cechowała się mocnym ideologicznym składnikiem. Niemniej jednak rewolucyjne zmiany w dyskursie historycznym $\mathrm{z}$ lat 90 . pozostawiły trwały ślad w świadomości historycznej mieszkańców Rosji, a także na koncepcjach opracowywanych przez historyków. Przykładowo, obecnie rosyjskie podręczniki nie negują faktu współpracy ZSRR z hitlerowskimi Niemcami, tajnych protokołów do paktu Ribbentrop-Mołotow i aktu agresji wobec Polski, jednak traktują to w swoisty sposób.

Trzeba zaznaczyć, że wydawane od 2004 roku materiały do nauczenia w szkołach historii można podzielić na dwie grupy (każda $\mathrm{z}$ których reprezentuje odrębną szkołę historyczną). Pierwsza grupa (liberalna) w łagodniej formie kontynuuje opracowywanie założeń z drugiej połowy lat 90., natomiast druga (patriotyczna) odradza wizję komunistycznych autorów. Dziś trudno przewidzieć, jaka koncepcja zwycięży w systemie szkolnictwa. Prawdopodobnie władze putinowskiej Rosji będą dążyły do wsparcia patriotycznego spojrzenia na historię. Jednak póki co analiza tekstów wykazała symbiozę obydwu szkół.

Widać to na przykładzie treści aktualnie wydawanej literatury szkolnej. „(...) polskie władze opuściły kraj. Tego samego dnia, 17 września, jednostki Armii Czerwonej wkroczyły na wschodnie tereny Rzeczypospolitej Polskiej" (Wołobujew, Kłokow, Ponomariow, Rogożkin, 2013). Podany fragment tekstu ukazuje, że autorzy nie ignorują przynależności okupowanych ziem do II Rzeczypospolitej. „Wschodnie tereny Rzeczypospolitej Polskiej” bowiem nie zostały zastąpione „terenami Zachodniej Białorusi i Ukrainy”. Jednak znów (jak i za czasów Związku Radzieckiego) w tekstach nie udało się odczytać prób potępienia stalinowskiej polityki, wręcz przeciwnie, jest ona uzasadniana zapotrzebowaniem szykującego się do wojny państwa. Wśród autorów szkolnych materiałów popularnością cieszy się koncepcja, która zakłada, iż radziecka agresja rozpoczęła się dopiero po upadku II Rzeczypospolitej Polskiej jako państwa suwerennego (Izmozik i in., 2015). Za ten moment uznano opuszczenie Polski przez rząd cywilny. Świadczy o tym następujący cytat: „Wojsko Polskie poniosło klęskę, polski rząd opuścił stolicę (...)” (Wołobujew, 2013). Podobna narracja już miała miejsce w radzieckich podręcznikach, lecz obecnie nie próbowano rozpatrywać jej zgodnie z paradygmatami marksizmu-leninizmu. Historycy rosyjscy uważają, że wkroczenie oddziałów Armii Czerwonej nastąpiło w sytuacji, kiedy Polska de juro i de facto przestała istnieć. Udowadniano to brakiem czynnego oporu ze strony władz polskich. Uwypuklano fakt poddania się Rosjanom straży granicznej, wojska polskiego i innych służb mundurowych. 
Analiza jakościowa wykazała, że narracja ujawnia dwojakie nastawienie do II Rzeczypospolitej. Przychylność do narodu polskiego koliduje z wrogością wobec państwa polskiego. Między innymi Polskę obarczano winą okupacji terenów do niej nienależących (Białorusi, Ukrainy oraz Litwy). „(...) [jednostki wojskowe] zajęły tereny Zachodniej Białorusi i Zachodniej Ukrainy, [tereny te] znajdowały się pod polską okupacją od zakończenia wojny polsko-bolszewickiej” (Daniłow, Kosulina, Brandt, 2012).

Rosyjskie podręczniki uzupełniają badany wątek tekstem opisującym dążenie ZSRR do zawarcia sojuszu z państwami Zachodu. Polsce zarzucają przeciwdziałanie pokojowej polityce Moskwy, opór radzieckim propozycjom zbiorowego bezpieczeństwa we Wschodniej Europie. „(...) Polska i państwa nadbałtyckie ostro zareagowały na propozycje Sowieckiego rządu, propozycja polegała na przejściu Armii Czerwonej przez ziemie polskie w przypadku niemieckiej agresji. (...) Jednak bez wspólnej granicy z III Rzeszą Armia Czerwona nie mogła działać (...)." (Daniłow, 2012).

Powyższe cytaty świadczą o tym, że autorzy rosyjskich podręczników próbują uzasadnić agresję na Polskę na różne sposoby. Podobny przekaz wiedzy odróżnia się od radzieckiego, gdyż radzieccy historycy nawet nie próbowali znaleźć argumentów przemawiających za tym, że do zbrojnej napaści doszło z winy II Rzeczypospolitej Polskiej, uznając inwazję za akt naturalny. Klarownie pokazują to wykorzystywane w podręcznikach określenia radzieckiej agresji. Za czasów Związku Radzieckiego nazywano to „wyzwoleńczym pochodem Armii Czerwonej” (oswoboditelnyj pochod RKKA), a teraz - „polskim pochodem Armii Czerwonej” (polskij pochod Krasnoj Armii) lub „radziecką inwazją na Polskę” (sowietskaja interwencia w Polsze).

Podsumowując analizę rosyjskiej literatury szkolnej, warta podkreślenia wydaje się ciągła ewolucja treści podręczników. Od początku i do połowy lat 90. książki wykorzystywane przez placówki oświatowe kontynuowały tradycję radzieckiej szkoły historycznej. Ignorowały one pakt Ribbentrop-Mołotow, nie wspominały agresji ZSRR na Polskę, omijały kwestię katyńską itd. (Gordiejewa, 2007).W drugiej połowie lat 90. sytuacja się zmieniła. Autorska narracja zaczęła uwzględniać polski punkt widzenia. Szkolne materiały omawiały wielką tragedię narodu polskiego: utratę niepodległości, okupację Kresów, masowe deportacje na Sybir. W tych latach uczniowie zapoznawali się ze zdarzeniami z września 1939 roku na zasadzie założenia o okupacyjnym charakterze przyłączenia Kresów do ZSSR. Na stornach podręczników znalazły się wzmianki o masowych aresztach i zabójstwie osób polskiego pochodzenia w ZSRR w latach 1939-1941. Po raz 
pierwszy rosyjskie szkoły udostępniły uczniom wizję historii pozbawioną zbędnego patriotyzmu, gdyż II Rzeczypospolita została przedstawiona jako ofiara roszczeń terytorialnych zarówno strony niemieckiej, jak i radzieckiej.

Na początku pierwszej dekady XXI wieku narracja szkolnej literatury znów zaczęła się zmieniać. $Z$ podręczników zaczęto usuwać wątki „o charakterze spornym” i antypatriotycznym. Między innymi zrezygnowano z naświetlenia następujących zagadnień: 17 września 1939 roku, okupacji Kresów, zbrodni katyńskiej. Obecnie udostępniane uczniom materiały naśladują narrację już zanalizowanych tekstów radzieckich. Trzeba zaznaczyć, że w kontekście tematu II wojny światowej na zajęciach $\mathrm{z}$ historii - kontynuując tradycję z lat 90. - omawiano masowe zbrodnie na polskich jeńcach i potępiano ludobójstwo Polaków. Jednak autorzy próbują to uzasadnić na różne sposoby. „.... 21857 oficerów i innych więźniów (policjantów, pracowników służb specjalnych itd.) zostało rozstrzelanych. Prawdopodobnie decyzja ta zapadła z powodu chęci ukarania „Białopolaków” za brutalny mord radzieckich jeńców w trakcie wojny 1920 roku” (Daniłow, 2012). Ilość radzieckich ofiar na Kresach Wschodnich w szacunkach różnych podręczników różni się.W niektórych podawano sprecyzowane 21857 (Daniłow, 2012), w innych mówiono o „kilkunastu tysiącach” (Izmozik, Żurawlowa, Rudnik, Ganielina, 2015). Aczkolwiek trzeba uznać to za znaczny postęp w przekazie wiedzy historycznej, gdyż wcześniej podobnego tematu w ogóle nie podnoszono, zastępując go tematem „wyzwolenia bratnich Białorusi i Ukrainy”, w którym Polacy w ogóle nie występowali.

\section{PODSUMOWANIE}

Analiza narracji podręcznikowej ujawniła, iż rosyjskie podręczniki, tak samo jak radzieckie, ignorują tematykę 17 września. Dana problematyka mieści się na marginesie oficjalnej historiografii. Poruszenie tego wątku bowiem przeszkadza polityce historycznej, która polega na kreowaniu obrazu ZSRR -wyzwoliciela narodów Europy. Jedynym wyjątkiem od podobnej reguły są podręczniki z drugiej połowy lat 90. Co więcej, obecnie zauważalna jest tendencja do przywrócenia radzieckich paradygmatów historycznych. Podręczniki wydawane w Rosji (wcześniej w ZSRR) mogą być scharakteryzowane jako posiadające treść nieprzychylną wobec Polski i Polaków, gdyż państwo polskie jest opisywane jako antagonista Rosji/ZSRR. Naukowcy ze wschodu z reguły nie traktują zachodniej Ukrainy i zachodniej Białorusi (które w okresie międzywojennym znajdowały 
się pod jurysdykcją Warszawy) jako integralnej części II Rzeczypospolitej Polskiej. Podobne stanowisko autorzy udowodniają powojennym porządkiem europejskim oraz etnicznymi granicami. Niewątpliwie w danej kwestii na pozycję historyków znaczny wpływ wywiera elita polityczna Federacji Rosyjskiej, która dąży do zakorzenienia w świadomości Rosjan myśli o sprawiedliwości powojennych granic. W Rosji, podobnie jak wcześniej w ZSRR, ukształtowała się wizja, zgodnie z którą Białorusini oraz Ukraińcy w ramach II Rzeczypospolitej stanowili prześladowaną mniejszość, która dążyła do zjednoczenia z bratnimi radzieckimi republikami. Dana koncepcja jest wykorzystywana w trakcie licznych politycznych rozgrywek na terenach postsowieckich, gdyż uzasadnia historyczne prawo Rosjan do obrony interesów „bratnich narodów” od Zachodu w postaci Rzeczypospolitej Polskiej.

Analiza tekstów źródłowych wykazała, iż rosyjski uczeń, który w poszukiwaniu wiedzy sięgnie jedynie do obowiązujących w szkole materiałów, nie dowie się nic o II wojnie światowej oraz roli ZSRR we wzniecaniu światowego konfliktu. Co więcej, rosyjskie podręczniki cechują się mocnym prorosyjskim nastawieniem i dominacją koncepcji wielkiej wojny ojczyźnianej, która zastępuje II wojnę światową. Podobna narracja ukształtowała się pod koniec lat 50. i nadal ma miejsce (za wyjątkiem krótkiego okresu w drugiej połowie lat 90.). Okupacja polskich ziem ciągle jest traktowana przez pryzmat zapotrzebowań Moskwy w trakcie przygotowania do walki z III Rzeszą. Niemniej jednak podobna wizja jest krokiem do przodu, gdyż w radzieckiej szkole w ogóle nie poruszano tego wątku, ograniczając temat wzmiankami o tym, że Kresy były okupowane przez Polskę.

Znaczne zaniepokojenie wywołuje trend przywrócenia do podręczników paradygmatów rozpracowywanych w latach 50.-80. II Rzeczpospolita znów jest uznawana za utwór sztuczny, za państwo nieodróżniające się od hitlerowskich Niemiec, gdyż okupowała Zachodnią Białoruś oraz Zachodnią Ukrainę. Ponadto treść materiałów wskazuje na to, że na wymienionych terenach przeprowadziła brutalną politykę (Szestakow, 2015). Wzmianek potępiających radziecką politykę w stosunku do Polaków w latach 1939-1941 jest coraz mniej. Dlatego też trzeba uznać, że główne założenie artykułu o tym, iż rosyjskie podręczniki do historii pomijają udział ZSRR w najeździe na II Rzeczpospolitą, w ten sposób kontynuując politykę historyczną Związku Radzieckiego, zostało potwierdzone. Z dużym stopniem prawdopodobieństwa można sugerować, że na opis 17 września i jego ewolucję znaczny wpływ wywierają relacje między Moskwą a Warszawą. Każde pogorszenie stosunków powoduje bowiem w kolejnych edycjach podręczników zaostrzenie narracji wobec Polski. 
Podsumowując, trzeba zaznaczyć, że w Federacji Rosyjskiej, podobnie jak kiedyś w ZSRR, narracja opisująca rozpoczęcie II wojny światowej w kontekście radzieckiej agresji na Polskę powinna być uznana za uproszczoną. Jednak poziom historycznej manipulacji w dzisiejszej szkolnej literaturze jest o wiele mniejszy niż w literaturze obowiązującej przed upadkiem ZSRR. Niestety autorom rosyjskich podręczników nadal brakuje dystansu przy opisie zdarzeń z minionych lat, zwłaszcza jeżeli chodzi o sprzeczne wątki, z których jeden bez wątpienia stanowi wrzesień 1939 roku. Trzeba jednak zaznaczyć: w literaturze szkolnej Rosji nie udało się odnaleźć upartego trzymania się interpretacji rodem z ZSRR.

BiBLIOGRAFIA:

Bagdarasiam, W.E., Abdułajew, W.E., Kłyniczkow, W.M., Łarionów, A.E., Morozow, A.J. (2009). Szkolnyj uczebnik istorii i gosudarstwiennaja politika. Moskwa: Naucznyj ekspiertka.

Berger, P. (2010). Społeczne tworzenie rzeczywistości. Warszawa: PWN. Gordiejewa, J.W. (2007). Istoriczeskije obrazy Polszy w uczebnikach N.W. Zagładina «Istorija Rossii i mira s driewniejszych wriemien do konca XX w.». Wostok-Zapad:problemy wzaimodiejstwija. Istorija,tradicyi, kultura: matieriaty Wsierossijskoj nauczno-prakticzeskoj konfieriencyi, poswiaszczennoj pamiati profiessora A. W. Edakowa, 2, 192-194.

Daniłow, A.A., Kosulina, Ł.G., Brandt, M.J. (2012). Istorija Rossii. XX-naczało XXI w. 9 kłas. Moskwa: Proswieszczenije.

Daniłow, A.A., Kosulina, Ł.G., Brandt, M.J. (2013). Istorija Rossii. XX-naczało XXI w. 9 kłas. Moskwa: Proswieszczenije.

Furajew, W.K. (1983). Nowiejszaja istorija dla 10 kłassa (1939-1982). Moskwa: Proswieszczenije.

Furajew, W.K. (1975). Nowiejszaja istorija (1939-1974). Moskwa: Proswieszczenije. Jepifanow, P.P., Fiedosow, I.A. (1965). Istorija SSSR dla 9-10 kłassow sriedniej szkoły. Moskwa: Proswieszczenije.

Ionow, I.N. (2001). Rossijskaja cywilizacyja. IX-naczało XX w. Moskwa: Proswieszczenije.

Izmozik, W.S., Żurawlowa, O.N., Rudnik, S.N., Ganielina, R.S. (2015). Istorija Rossii. 9 kłass. Moskwa: Izdatielskij centr WIENTANA-GRAF. Kim, M.P. (1969). Istorija SSSR. Epocha socyalizma. Uczebnoje posobije dla 9-10 kłassow sriedniej szkoły. Moskwa: Proswieszczenije.

Kim, M.P. (1980). Istorija SSSR (1938-1978 gg.). Moskwa: Proswieszczenije.

Kisielew, A.F., Popow W.P., (2016). Istorija. Istorija Rossii. 9 klas. Moskwa: Drofa. Kreder, A.A. (2005). Nowiejszaja istorija zarubieżnych stran 1914-1997. 9 klass. Moskwa: Centr Gumanitarnogo Obrazowanija. 
Lazari, A., Nadskakuła, O., Żakowska, M. (2007). Zaprogramowanie kulturowe narodów Europy. Łódź.

Lazari, A. Rongińska, T. (2006). Polacy i Rosjanie: przezwyciężanie uprzedzeń. Łódź. Łykoszyna, Ł.S. (2016). Polsza i Polaki w rossijskom obszczestwiennom diskursie. Wosprijatije jewropiejskich stran $w$ Rossii, 12, 65-84.

Lewandowskij, A .A. (2013). Istorija Rossii, XX-naczało XXI wieka. 11 kłass. Moskwa: Proswieszczenije.

Maresz, T. (2017). Podręcznik szkolny narzędziem kształtowania świadomości historycznej młodzieży. Analiza porównawcza polskich, rosyjskich, białoruskich i ukraińskich podręczników do historii z przełomu XX i XXI wieku. W: G. Pańko, M. Skotonicka-Palka, B. Techmański (red.). Młodzież w perspektywie edukacyjnej, społecznej, kulturowej (s. 123-136). Wrocław-Kraków: Avalon.

Maresz, T. (2017). Polska i Polacy w radzieckiej szkolnej narracji podręcznikowej. Bydgoszcz: Uniwersytet Kazimierza Wielkiego.

Pienkratowa, A.M. (1952). Istorija SSSR. Czast' 3 (1894-1951). Moskwa: Uczpiedgiz.

Suchoński, A. (2005). Opinie o Polsce i Polakach w podręcznikach naszych sąsiadów. W: M. Kosman (red.). Kultura polityczna w Polsce - swoi i obcy. (s. 5-19). Poznań: UAM. Plenkow, O.J. Andriejewskaja, T.P. Szewczenko, S.W. Miasnikowa, B.C. (2013). Istorija. Wsieobszczaja istorija. 11 kłass. Moskwa: Izdatielskij centr WIENTANA-GRAF. Szestakow, W.A. (2012). Istorija Rossii, XX-naczało XXI wieka. 11 kłass. Moskwa: Proswieszczenije.

Suchoński, A. (2008). Polacy na kartach zagranicznych podręczników do nauczania historii. W: S. Roszak, M. Strzelecka, A. Wieczorek (red.). V Toruńskie Spotkania Dydaktyczne V. Polska -Europa - Świat w szkolnych podręcznikach historii (s.10-15). Toruń.

Wojdon J., Obraz Polski we współczesnych rosyjskich podręcznikach do historii. W: S. Roszak, M. Strzelecka, A. Wieczorek (red.). V Toruńskie Spotkania Dydaktyczne V. Polska - Europa - Świat w szkolnych podręcznikach historii (s. 53-61). Toruń.

Wołobujew, O.W., Kłokow, W.A., Ponomariow, M.W., Rogożkin, W.A., (2013). Istorija. Rossija i mir. 11 kłass. Moskwa: Drofa.

Wołobujew, O.W., Żurawlew, W.W., Nienarokow, A.P., Stepaniszczew, A.T., (2010). Istorija Rossii. XX-naczało XXI w. 9 kłas. Moskwa: Drofa. 